\title{
Geomorfológiai tanulmányút Morvaországban - barlangoktól a bányákig
}

(Masaryk Egyetem, Brno, Csehország, 2015. május 18-26.)

\author{
Józsa Edina $^{{ }^{*}}$ - Tóth Gabriella ${ }^{1}$ \\ ${ }^{I}$ Pécsi Tudományegyetem Természettudományi Kar Földtudományok Doktori Iskola \\ "E-mail: edina.j0zs4@gmail.com
}

DOI: 10.17799/2015.1.21

A Pécsi Tudományegyetem geomorfológia iránt érdeklődő hallgatói immár második alkalommal vehettek részt Campus Hungary ösztöndíj keretében szervezett komplex terepgyakorlaton, melynek helyszíne ezúttal a természeti és kultúrtörténeti értékekben bővelkedő Morvaország, a Cseh-Morva-medence és -dombvidék volt. E terület sajátossága, hogy keverednek a domborzat alap morfológiai elemei, megtalálhatóak itt alföldek és medencék, dombságok és hegyvidékek. Ezt a morfológiai képet változtatta meg az ember és alakította ki a morva tájat, melyet több világörökségi helyszínnel is elismertek. Ennek a Kárpát-medencén kívüli vidéknek a megismerése hasznos volt a hallgatók számára, hiszen a hazai tájakat is kialakító legfőbb geomorfológiai folyamatok áttekinthetőek, párhuzamok és különbségek kereshetőek a magyar tájakkal, felszínformákkal.

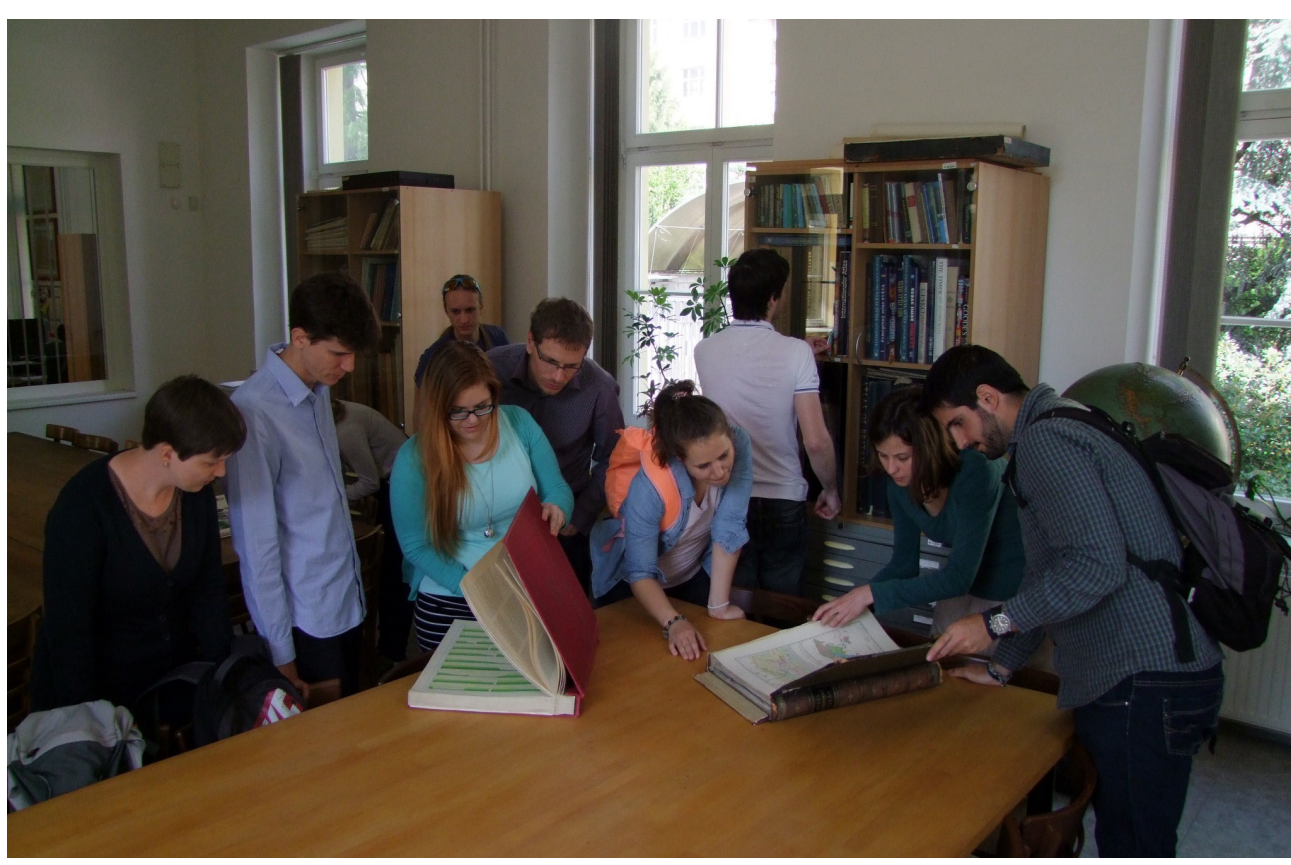

1. ábra: Látogatás a Földrajzi Tanszék térképtárában. (Fotó: Varga G.)
A csoportot fogadó intézmény a brnoi Masaryk Egyetem Földrajzi Tanszéke volt (1. ábra). A tanszék vezetője, Dr. Petr Dobrovolný felvilágosítást adott a képzési rendszerről, a hallgatók tanulmányi és kutatási lehetőségeiről, a geográfus diploma értékéről a cseh munkaerőpiacon, illetve a szak hallgatólétszám-csökkenésből eredő nehézségeiről. Emellett a hallgatók megismerkedhettek az ott zajló kutatásokkal, az alkalmazott módszerekkel és az elérhető eszközparkkal is. A tanszék kiemelkedő kutatási témái közé tartozik a természeti veszélyek és katasztrófák vizsgálata, a történeti klímaingadozás rekonstrukciója, karsztos és folyóvízi felszínformák geomorfológiai térképezése, illetve egyre nagyobb hangsúlyt kapnak a dendro-geomorfológiai vizsgálatok is.

A tanulmányút során minden lehetőséget kihasználtunk, hogy a különböző természetes és antropogén tájakat megismerhessük. A Pannon-medencéből kifelé vezető úton érintettük a Dévényi-várat, ahonnan belátható volt a Morva dunai torkolata, a Kárpátok kezdő tagja (Hainburgi-rög) mellett fö folyónk áttörése. Már cseh vidéken megtekinthettük a Lednice-Valtice kultúrtájat és mesterségesen kialakított tórendszerét, amelyet „Európa kertje"-ként az UNESCO Világörökségek között tartanak számon. A Dívčí erődítmény romjaihoz felkapaszkodva egyik irányban a Pálava mészkőhegység sztyepp vegetációval borított védett tájképi területét (2. ábra), míg a másik irányban Pavlov település 


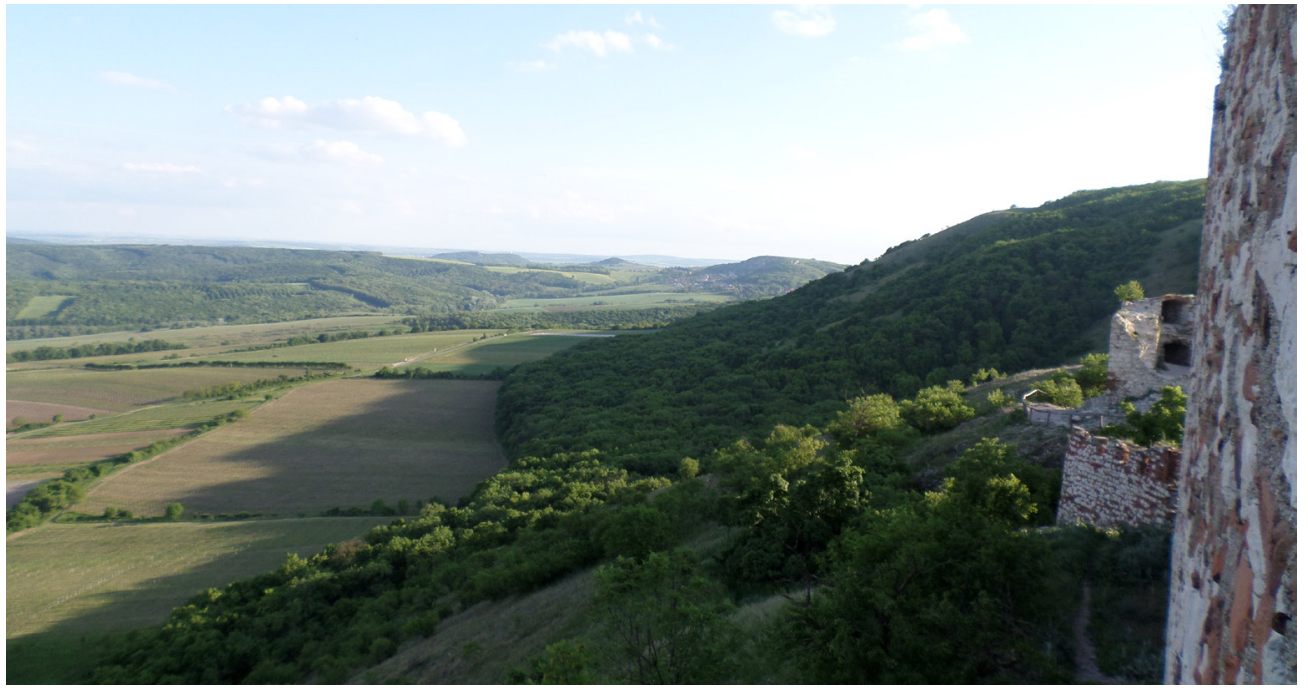

2. ábra: Morva tájkép (Fotó: Józsa E.)

közelében a 11. század óta tartó szőlőművelés domborzatra gyakorolt hatásait figyelhettük meg.

$\mathrm{Az}$ út során igyekeztünk a terepi munkára helyezni a hangsúlyt, ám emellett a jelentősebb morva városok kultúrtörténeti értékeinek megismerésére is szakítottunk időt. Ez utóbbi részét képezte a brnói városnézés, ahol megtekintettük a magyar vonatkozásokkal is bíró Špilberk várat (Kazinczy Ferenc raboskodott itt), a Zöldségpiacot, a Szent Péter és Pál katedrálist, a mumifikálódott szerzeteseket őrző Kapucinusok templomát és természetesen érintettük az Óvárosháza térségét, ahol a brnói sárkány és a kerék legendájával ismerkedtünk meg. Kisebb városnézésre adódott lehetőségünk Pécs testvérvárosában, Olomouc-ban avagy Olmützben, ahol a város Morva-parti legalacsonyabb részeitől eljutottunk a neogótikus Szent Vencel templomig, amely hihetetlen méreteivel (tornya közel 100 méter magas) nyügözi le az érdeklődőket. A megtekintett történelmi értékek között említhetjük Pernštejn kastélyát is (3. ábra). A 13. században a kastély eredeti magja egy kristályos kőzetekből álló kiszögellésen épült fel, amely éles kanyarra készteti a vár alatt húzódó vízfolyást is. A kastély érdekessége, hogy az évszázadok alatt nem tudták elfoglalni, amit többek között a rendkívül jó elhelyezkedésének köszönhet.

A terepbejárások során részt vettünk Dr. Zdeněk Máčka vezetésével a földrajz BSc szakos hallgatók terepgyakorlatán, Brnotól ÉNy-ra a Bílý-patak völgyében (4. ábra). A terepi munka magában foglalta a vízfolyás hidrológiai és morfometriai jellemzőinek mérését.

A tanulmányutunk egyik fénypontja volt a Morva-karszton tett gyalogos túra. Ez a térség Közép-Európa legnagyobb karsztos területe, melynek alapját adó devon kori tengerüledékből álló mészkőterület $100 \mathrm{~km}^{2}$-re terjed ki és több mint 1100 barlang, szakadék és egyéb karsztos forma teszi a karsztokon végbemenő folyamatok egyik legjobb bemutatóhelyévé. A gazdag formakincs jelzi a karszt korát is (kb. 320 millió év), ugyanis a még aktív, fejlődő szakaszok a már inaktív, összetöredezett alakzatokkal együtt láthatóak. A túra során a Punkva-barlang bejárására volt lehetőségünk. Száraz szakaszán hatalmas méretü sztalagmitok és sztalagtitok díszítik a termeket, néhol tejfehéren, ami a szennyeződés-mentes képződés jele. A vizes szakasz kezdete elött az egykori barlang plafonja beszakadt és egy 140 m mély szakadékot hozott létre, ez a Macocha-szakadék. A beszakadásnak köszönhetöen vált a felszínről is láthatóvá a Punkva-patak, amelynek a neve is búvópatakot jelent. Saját meglátásunk szerint a barlangnak nagy terhelést jelent a hatalmas turista tömeg, amely a jövőben valószínúleg problémákat okozhat még (a világítás és annak melege algák számára tökéletes életkörülményeket biztosít, a túlzott kiépítés pedig már feltehetően most is visszafordíthatatlan következményekkel járt).

Az Északnyugati-Kárpátok flis övezetéhez sorolható területen, Halenkovice település mellett bejártuk egy nagy kiterjedésü és rendszeresen felújuló csuszamlás környékét is. A csuszamlás fő kiváltó oka a kutatások szerint az extrém csapadékmennyiség lehetett 1997-ben, többszöri felújulására a megfelelő földtani és domborzati viszonyok miatt számítottak a kutatók. A területen

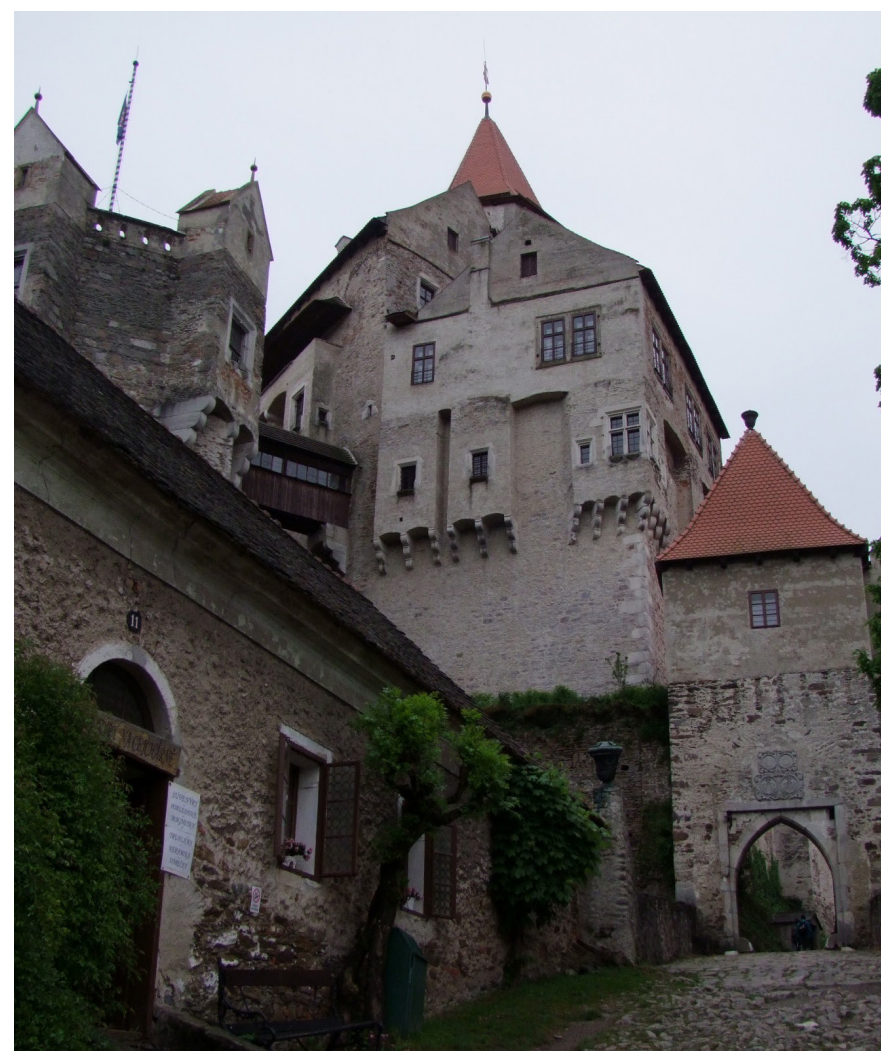

3. ábra: A Pernstejn kastély. (Fotó: Varga G.) 
megtaláltuk a stabilizációs munkálatok, a vízelvezetés nyomait, illetve a korábbi mozgásokra és szuffóziós folyamatokra következtethettünk a fák törzsének íveltségéből, a talaj látható repedéshálózatából.

Tömegmozgásos folyamatok nyomait kerestük a Zlín környéki terepbejárásunk során is. A település erősen csuszamlás-veszélyes, mivel flis területekre épült, ráadásul a viszonylag meredek lejtők,

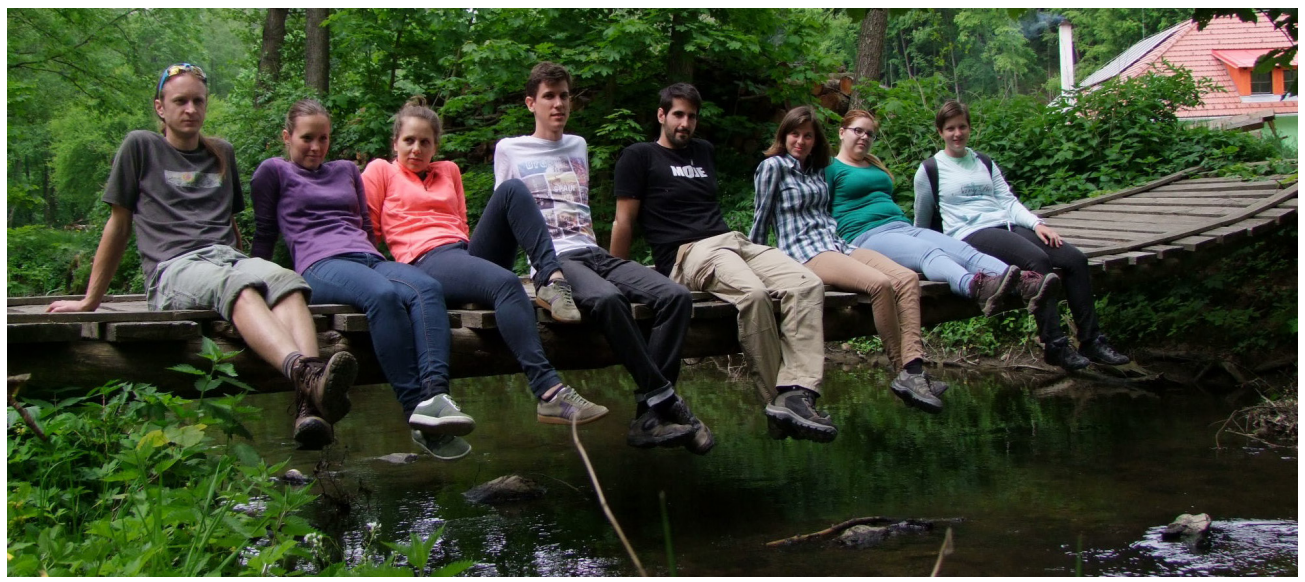
amelyeket a lakosság sürün beépített szintén megteremtik például csuszamlások kialakulásának feltételeit.

Természeti és társadalmi szempontból is érdekes volt a Rožnov pod Radhoštěm település melletti „Oláh Skanzen” megtekintése. Amúzeum tulajdonképpen egy falu, amely a Morva-Sziléziai-Beszkidekben, Wallachia régió - történeti, kulturális, építészeti viszonyainakmegőrzésérehivatott.

A tanulmányutat Ostrava környékének megismerésével zártuk. A Cseh Köztársaság egykori „,acél szíve” a bányászat, a vas- és acélipar fejlődésének és jelenlegi állapotának bemutatására számos lehetőséget kínál. A település a vidék leginkább szennyezett levegőjü városa, ami nagyban köszönhető a még mindig üzemelö acélipari és bányászati vállalatoknak. Ostravában található Csehország legnagyobb bányászati múzeuma, a Landek Park, az egykori Anselm bánya (5. ábra). Az Odra és Ostravice vízfolyások összefolyásánál álló Landek-domb térsége geológiai, történelmi és természeti értelemben is kiemelkedő értéket képvisel, így részét képezi az UNESCO Világörökségeknek. A földalatti bányászati kiállítás be-

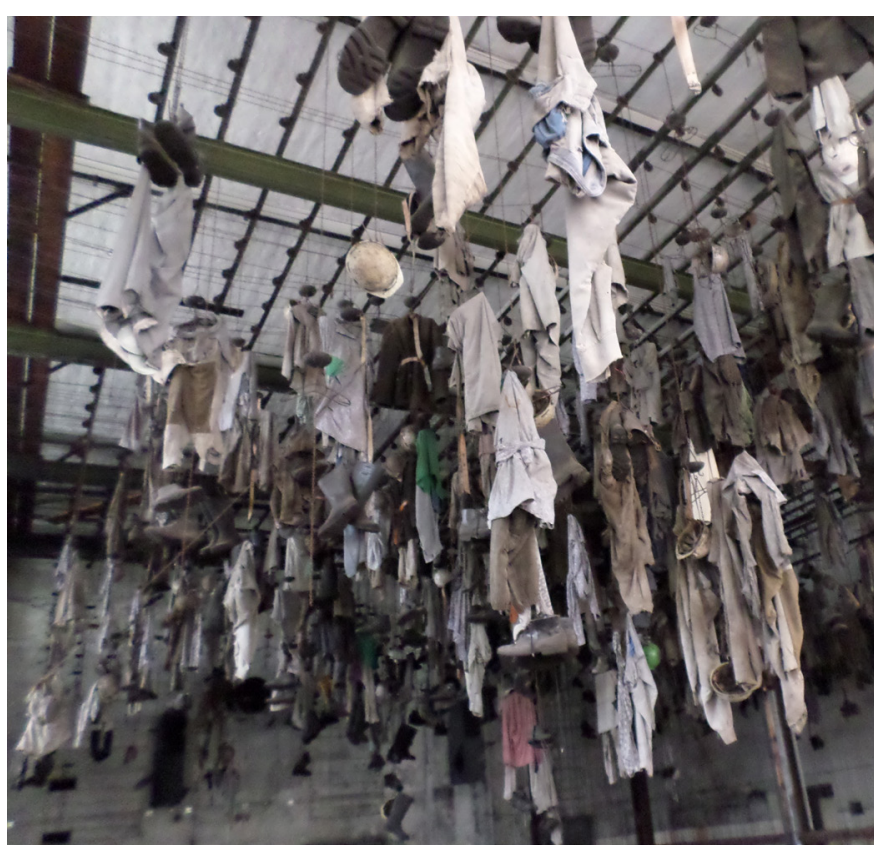

mutatja a korai, kézi szén-bányászati módszereket, valamint a vágatszerü bemutatótermekben a gépesített frontfejtés eszközeit egyaránt. Az igazi Ostrava megismerésének elengedhetetlen eleme volt Dolni Vitkovice városrész körbejárása, amely napjainkra egyre inkább kulturális célokat betöltő, hatalmas gyárépületekkel tüzdelt posztindusztriális térség. Itt a 19. század elejétől egészen a 20. század végéig zajlott szénbányászat és nyersvasgyártás. Napjainkban a leromlott állapotú gyárépületek, gyárkémények, rozsdásodó csővezetékek jellemzik az épületegyüttest, amelyek mellett viszont modern galériák, tudományos bemutatóterek és fesztiválhelyszínek bukkannak fel egyre növekvő számban.

Összességében úgy véljük, hogy a tanulmányút hasznos volt a hallgatók számára, hiszen amellett, hogy bejárhattuk Morvaország legfontosabb városait és UNESCO Világörökségi helyszíneit, lehetőségünk adódott angol nyelvtudásunk fejlesztésére és terepi tapasztalatokkal is gazdagodtunk. Reményeink szerint a későbbiekben akár a két egyetem közötti nemzetközi összeköttetések révén, akár tudományos projektekben való összefogások mentén tovább ápolhatjuk a Pécsi Tudományegyetem és a Masaryk Egyetem geográfusai közötti jó kapcsolatot.

5. ábra: Egy korszak véget ért - 1991-ben beszúntették a szén kitermelését az Anselm bányában. (Fotó: Józsa E.) 
